\title{
PEMANFAATAN KULIT BUAH NAGA MERAH (Hylocereus polyrhizus) SEBAGAI TEPUNG UNTUK PEMBUATAN COOKIES
}

\section{Utilization of Red Dragon Fruit (Hylocereus polyrhizus) Peel as Flour for Making Cookies}

\author{
Nia Rochmawati \\ Program Studi Seni Kuliner, Akademi Kuliner dan Patiseri OTTIMMO Internasional Surabaya \\ Jl. Bukit Telaga Golf Blok TC4 No 2-3 Citraland Surabaya \\ Penulis Korespondensi, Email: Niaarochmawati@ottimmo.ac.id
}

\begin{abstract}
ABSTRAK
Buah naga merah merupakan buah yang dapat tumbuh di Indonesia serta dapat dimanfaatkan buahnya sebagai jus, selai, dan produk lain sehingga menghasilkan kulit buah naga (KBN) sebagai hasil samping. Penelitian ini bertujuan untuk meneliti kandungan nutrisi dari cookies yang terbuat dari tepung KBN serta mengetahui klaim sumber serat pada cookies sesuai BPOM. Proporsi yang digunakan pada pembuatan cookies yang terbuat dari KBN : tepung terigu yaitu secara berturut-turut 100:0, 90:10 dan 80:20. Kandungan nutrisi yang diteliti yaitu kadar air, abu, protein, lemak dan serat kasar. Hasil menunjukkan bahwa cookies yang terbuat dari tepung KBN memiliki kadar serat dan kadar abu yang lebih besar dibandingkan dengan kontrol. Simpulan dari penelitian ini adalah cookies yang terbuat dari KBN dapat meningkatkan nilai nutrisi cookies serta proporsi cookies terbaik berdasarkan standar yaitu 90:10 dengan kadar air $8.06 \%$, kadar abu $6.81 \%$, kadar protein $5.63 \%$, kadar lemak $27.03 \%$, kadar karbohidrat $52.47 \%$, dan kadar serat $31.26 \%$.
\end{abstract}

Kata kunci: Analisis Proksimat, Cookies, Kulit Buah Naga, Serat Kasar

\section{ABSTRACT}

Red dragon fruit (Hylocereus polyrhizus) (RDF) is well known and abundant fruit in Indonesia, creating red dragon fruit peel (RDP) as food waste. This study was carried out to investigate the nutritional composition of cookies made from RDF flour and find out the fiber source claim of cookies based on BPOM standard. The nutritional composition measured were moisture content, ash, crude protein, crude fat, carbohydrate and crude fiber of cookies with the proportion of RDP flour: wheat flour 100:0, 90:10, and 80:20, respectively. Results showed that cookies made from RDP flour had higher fiber and ash than the control. The conclusion of this research were the cookies made from RDP flour improve the nutritional quality of cookies and the best proportion according to standard is 90:10 with the moisture content, ash, protein, fat, carbohydrate and fiber are 8.06\%, 6.81\%, 5.63\%, 27.03\%, 52.47\% and $31.26 \%$, respectively.

Keyword: Cookies, Fiber, Proximate Analysis, Red Dragon Fruit Peel

\section{PENDAHULUAN}

Kue kering atau lebih dikenal dengan cookies merupakan salah satu jenis produk bakery yang mudah diterima oleh semua kalangan karena memiliki nilai nutrisi, umur simpan yang panjang, harga yang terjangkau, serta memiliki aspek kenyamanan bagi konsumen (convenience aspect) (Akubor, 2003). Secara umum cookies terbuat dari 3 bahan utama yaitu tepung, gula dan mentega (Wani, et al., 2015). Cookies dapat juga digunakan sebagai produk pangan yang dapat disubtitusi bahan bakunya, misalnya tepung terigu, sehingga dapat meningkatkan nilai nutrisi tertentu. Hal ini dikarenakan cookies tidak memerlukan gluten untuk 
proses pengembangan (Arshad, et al., 2007; Septiani, 2016). Beberapa bahan yang pernah digunakan untuk mensubtitusi tepung terigu dalam pembuatan cookies antara lain kulit buah naga putih (Ho and Nadratul, 2016), ubi jalar (Septiani, 2016) dan kacang merah (Praptiningrum, 2015). Selain itu, Fauziah dan Yunianta (2019) juga pernah memanfaatkan tepung mocaf dalam pembuatan muffin sebagai diversifikasi produk bagi konsumen yang tidak dapat mengkonsumsi gluten. Hal ini membuktikan bahwa tepung terigu pada produk cookies dapat disubtitusi dengan bahan lain.

Buah naga termasuk kedalam spesies kaktus yang terdiri dari buah naga merah (Hylocereus polyrhizus), buah naga putih (H. undatus) dan buah naga kuning (Selenicereus megalanthus) (Nerd, et al., 2002; Hoa, et al., 2006). Buah naga merah memiliki kandungan air dan serat yang tinggi. Kandungan serat pangan kasar pada buah naga merah adalah sebesar 10.1 gram per 100 gram. Selain itu kandungan vitamin A, C dan E pada buah ini secara berturut-turut adalah $102.13 \mu \mathrm{g}, 540.27 \mu \mathrm{g}$ dan $105.67 \mu \mathrm{g}$ per 100 gram berat kering (Hadi et al., 2016). Buah naga merah biasanya dikonsumsi secara langsung atau diproses sebagai jus, permen, es krim, sirup dan lain sebagainya sehingga menghasilkan produk samping berupa kulit sebanyak $22 \%$ per buah naga merah. Bahkan kulit buah naga merah juga memiliki pektin, pigmen betasianin, dan serat pangan dengan rasio serat pangan larut: serat pangan tidak larut sebesar 1 : 3.8 (Hernawati et al., 2018). Penelitian mengenai pemanfaatan cookies dari kulit buah naga putih pernah dilakukan Ho dan Nadratul (2016). Pada penelitian tersebut kulit buah naga putih digunakan sebanyak 5.10 dan $15 \%$ sebagai pengganti tepung terigu. Hasil yang diperoleh menunjukkan bahwa penambahan kulit buah naga akan mempengaruhi kandungan serat, abu dan karbohidrat pada cookies.

Kandungan protein, lemak, abu dan serat pada kulit buah naga merah menurut Simangunsong et al. (2014) secara berturut-turut adalah 8.98\%, 2.60\%, 18.76\% dan $25.56 \%$. Serat pangan merupakan bagian dari karbohidrat yang tidak dapat dicerna oleh tubuh (Lairon, et al., 2005; Montonen, et al., 2003; Butcher et al., 2010). Serat pangan dikategorikan menjadi dua berdasarkan sifat kelarutannya pada air, yaitu serat pangan larut air (soluble dietary fiber) dan serat pangan tidak larut air (insoluble dietary fiber). Menurut BPOMa (2016), kebutuhan serat dewasa rata-rata 30 gram per hari. Suatu makanan dapat diklaim sebagai sumber serat apabila memenuhi 3 gram per 100 gram berat padat suatu makanan (BPOM $\left.{ }^{b}, 2016\right)$. Selain itu, pada Pasal 6 Peraturan BPOM ${ }^{b}$ (2016), pangan olahan yang mencantumkan klaim pada label harus memenuhi asupan per saji tidak lebih dari $18 \mathrm{~g}$ lemak total, $4 \mathrm{~g}$ lemak jenuh, 60 $\mathrm{mg}$ kolesterol dan $300 \mathrm{mg}$ natrium. Sehingga perlu dilakukan penelitian untuk mengetahui cookies yang terbuat dari kulit buah naga dapat memenuhi klaim sumber serat berdasarkan BPOM serta mengetahui karakteristik kimia (kadar air, protein, lemak, karbohidrat dan abu) cookies kulit buah naga merah.

\section{BAHAN DAN METODE}

\section{Bahan}

Bahan yang digunakan dalam pembuatan tepung adalah kulit buah naga merah (Hylocereus polyrhizus) yang didapatkan dari Surabaya. Bahan yang digunakan dalam pembuatan cookies antara lain tepung terigu berprotein 7\%, margarin, gula pasir, susu, gula pasir, telur, baking powder dan garam.

\footnotetext{
Alat

Alat yang digunakan dalam pembuatan cookies antara lain pengering kabinet (omron), oven (kitchen), blender (signora), sendok stainless dan baskom.

\section{Desain penelitian}

Formulasi dalam pembuatan cookies terdiri dari empat rasio, yaitu rasio tepung terigu: tepung kulit buah naga merah yaitu 100:0 (C1), 0:100 (C2), 10:90 (C3) dan 20:80 (C4).
} 


\section{Tahapan Penelitian}

Pembuatan Tepung Kulit Buah Naga (modifikasi Ho and Nadratul, 2016)

Kulit buah naga dipisahkan dari buah naga merah secara manual. Kulit buah naga selanjutnya di blanching selama satu hingga dua menit. Setelah proses blanching, kulit buah naga dihancurkan dalam food processor untuk memperluas permukaan sehingga proses pengeringan akan semakin cepat. Kemudian kulit buah naga merah dikeringkan dalam oven bersuhu $60^{\circ} \mathrm{C}$ selama 20 jam untuk kemudian dihaluskan menggunakan blender dan diayak menggunakan ayakan 40 mesh.

\section{Pembuatan Cookies (modifikasi Wulandari et al., 2016)}

Proses pembuatan cookies dimulai dengan mencampur tepung kulit buah naga dan tepung terigu dengan berbagai macam proporsi (Tabel 1). Tepung kering kemudian dicampur dengan gula, baking powder, margarin, gula, susu dan telur hingga terbentuk adonan. Adonan ditimbang sebanyak masing-masing 5 gram dan dibentuk bulat pipih. Kemudian adonan di panggang selama 20 menit pada suhu $150^{\circ} \mathrm{C}$.

Tabel 1. Bahan yang digunakan untuk pembuatan cookies pada berbagai proporsi

\begin{tabular}{ccccc}
\hline Bahan (gram) & C1 & C2 & C3 & C4 \\
\hline Tepung Kulit Buah Naga & 0 & 100 & 90 & 80 \\
Tepung terigu & 100 & 0 & 10 & 20 \\
Margarin & 70 & 70 & 70 & 70 \\
Gula & 50 & 50 & 50 & 50 \\
Susu & 30 & 30 & 30 & 30 \\
Telur & 6 & 6 & 6 & 6 \\
Baking powder & 1 & 1 & 1 & 1 \\
Garam & 1 & 1 & 1 & 1 \\
\hline
\end{tabular}

\section{Analisis Kimia Cookies}

Analisis kimia cookies meliputi analisis kadar air metode oven (AOAC, 1995), kadar protein metode kjeldahl (AOAC, 1995), kadar abu metode gravimetri atau furnace (AOAC, 1995), kadar lemak metode soxhlet (AOAC, 1995), kadar karbohidrat by difference (AOAC, 1995) serta analisis kadar serat metode hidrolisis asam basa.

\section{HASIL DAN PEMBAHASAN}

\section{Kadar air cookies}

Kadar air merupakan salah satu senyawa substansial pada produk pangan karena akan mempengaruhi umur simpan suatu produk. Menurut Fatkurahman et al. (2012) salah satu proses penting selama pemanggangan yaitu penguapan air. Berdasarkan Tabel 2 dapat dilihat bahwa produk cookies pada semua proporsi memiliki kadar air lebih dari $5 \%$. Kadar air pada cookies yang tinggi disebabkan kandungan adanya kandungan serat pada kulit buah naga, dimana serat memiliki sifat mengikat air. Hal ini didukung oleh Hood (1980), bahwa serat dalam suatu bahan dapat mengikat air dan walaupun dilakukan pemanasan, air yang diuapkan relatif kecil dan kandungan air yang tertinggal dalam bahan masih ada. Berdasarkan penelitian Simangunsong et al. (2014) kadar serat dalam kulit buah naga merah yaitu $25.56 \%$. Menurut SNI (2011), syarat mutu kadar air untuk biskuit atau cookies yaitu maksimal 5\%, sehingga berdasarkan hal tersebut diketahui bahwa produk cookies ini masih belum memenuhi persyaratan SNI.

\section{Kadar abu cookies}

Kadar abu pada kulit buah naga merah yaitu 2.60\% (Simangunsong, 2014), lebih besar dibandingkan dengan kadar abu pada tepung terigu berkisar antara $0.25-0.60 \%$ (Astawan, 2008). Berdasarkan pada Tabel 2, dapat dilihat bahwa cookies yang terbuat dari kulit buah naga juga memiliki kadar abu yang lebih besar dibandingkan dengan kontrol. 
Semakin banyak kulit buah naga yang ditambahkan semakin banyak pula kadar abu yang terukur.

Kadar abu tertinggi didapatkan dari cookies dengan proporsi $100 \%$ kulit buah naga merah (C2) yaitu 7.18\%, sedangkan kadar abu terendah didapatkan dari cookies kontrol (C1) yaitu $1.41 \%$. Kadar abu yang lebih besar pada cookies dengan penambahan kulit buah naga dibandingkan dengan kontrol diasosiasikan karena kandungan mineral pada kulit buah naga. Hal ini sejalan dengan penelitian Ho and Nadratul (2016) yang menyebutkan bahwa penambahan kulit buah naga putih sebanyak 15\% pada pembuatan cookies juga lebih besar dibandingkan kadar abu pada cookies kontrol, yaitu $3.11 \%$.

Tabel 2. Hasil Pengujian Cookies dengan Berbagai Proporsi

\begin{tabular}{|c|c|c|c|c|c|c|}
\hline $\begin{array}{l}\text { Proporsi } \\
\text { tepung } \\
\text { terigu : } \\
\text { kulit buah } \\
\text { naga } \\
\text { merah }\end{array}$ & $\begin{array}{l}\text { Kadar Air } \\
(\%)\end{array}$ & $\begin{array}{l}\text { Kadar } \\
\text { Abu (\%) }\end{array}$ & $\begin{array}{l}\text { Kadar } \\
\text { Protein } \\
(\%)\end{array}$ & $\begin{array}{l}\text { Kadar } \\
\text { Lemak } \\
(\%)\end{array}$ & $\begin{array}{l}\text { Kadar } \\
\text { Karbohidrat } \\
(\%)\end{array}$ & $\begin{array}{l}\text { Kadar } \\
\text { Serat (\%) }\end{array}$ \\
\hline $\mathrm{C} 1$ & 7.15 & 1.41 & 8.02 & 22.71 & 60.7 & 13.49 \\
\hline $\mathrm{C} 2$ & 7.21 & 7.18 & 4.37 & 21.09 & 60.15 & 29.87 \\
\hline C3 & 8.06 & 6.81 & 5.63 & 27.03 & 52.47 & 31.26 \\
\hline C4 & 7.56 & 6.75 & 5.44 & 25.45 & 54.8 & 24.38 \\
\hline
\end{tabular}

\section{Kadar Protein cookies}

Kadar protein (Tabel 2) pada cookies yang terbuat dari kulit buah naga pada semua proporsi memiliki kadar yang lebih rendah dibandingkan dengan kontrol. Protein pada proporsi $100 \%$ kulit buah naga merah masih belum sesuai dengan standar mutu SNI cookies karena memiliki kadar protein $<5 \mathrm{~g} / 100 \mathrm{gram}$, sedangkan pada semua proporsi lainnya telah sesuai dengan standar mutu SNI cookies. Protein pada cookies berasal dari telur dan tepung terigu yang digunakan (Welli, 2012). Sehingga semakin banyak tepung kulit buah naga yang ditambahkan semakin sedikit kadar protein yang terukur. Kadar protein tepung terigu yang digunakan adalah $8 \%$, sehingga penambahan tepung terigu akan meningkatkan kadar protein pada cookies.

\section{Kadar Lemak cookies}

Kadar lemak pada semua proporsi cookies menunjukkan bahwa cookies memiliki kadar lemak yang tinggi (>20\%). Kadar lemak yang tinggi seperti terlihat pada Tabel 2 diduga disebabkan oleh banyaknya margarin dan jenis susu yang ditambahkan. Pemberian kulit buah naga pada cookies hanya berpengaruh sebesar $2.60 \%$ dalam pemberian kadar lemak (Simangunsong et al., 2014). Sehingga untuk menurunkan kadar lemak diperlukan reformulasi kembali untuk jumlah dan jenis margarin serta susu yang digunakan. Namun, kadar lemak yang tinggi $>20 \mathrm{~g} / 100$ gram ini masih sesuai dengan BPOM $^{\mathrm{b}}$ (2016) yang menyebutan bahwa pangan olahan yang mencantumkan klaim pada label harus memenuhi asupan per saji tidak lebih dari $18 \mathrm{~g}$ lemak total, $4 \mathrm{~g}$ lemak jenuh, $60 \mathrm{mg}$ kolesterol dan 300 mg natrium (Tabel 3).

\section{Kadar serat cookies}

Serat pangan merupakan bagian dari karbohidrat yang tidak dapat dicerna oleh tubuh (Lairon, et al., 2005; Montonen, et al., 2003; Butcher et al., 2010). Salah satu manfaat serat pada kulit buah naga menurut Hernawati et al., (2018) yaitu menurunkan kolesterol melalui mekanisme penghambatan sintesis asam lemak. Penelitian dilakukan secara in vivo dengan memberikan bubuk kulit buah naga. Hasil menunjukkan bahwa terjadi penurunan total kolesterol, trigliserida dan LDL.

Suatu makanan dapat diklaim sebagai sumber serat apabila memenuhi 3 gram per 100 gram berat padat suatu makanan (BPOM $\left.{ }^{b}, 2016\right)$. Kadar serat pada cookies pada semua 
proporsi penambahan tepung kulit buah naga menunjukkan nilai yang lebih tinggi dibandingkan dengan kontrol. Hal ini sejalan dengan Ho and Nadratul (2016), yang menunjukkan bahwa cookies dengan penambahan tepung kulit buah naga putih memiliki kadar serat yang lebih tinggi dibandingkan kontrol.

\section{Informasi nilai gizi}

Informasi nilai gizi merupakan daftar kandungan zat gizi pangan pada label pangan sesuai dengan format yang dibakukan. Terdapat informasi takaran saji dalam informasi nilai gizi. Takaran saji merupakan jumlah pangan olahan yang wajib dikonsumsi dalam satu kali makan (BPOM, 2015). Takaran saji pada cookies ini yaitu $35 \mathrm{gram}$. Hal ini disesuaikan dengan BPOM (2015) yang menyebutkan bahwa takaran saji cookies memiliki rentang 20-40 gram. Informasi nilai gizi cookies dengan proporsi tepung terigu : tepung kulit buah naga (10:90) (C3) dinilai sebagai perlakuan terbaik berdasarkan beberapa standar mutu cookies seperti pada Tabel 3 dibawah ini.

Tabel 3. Proporsi cookies perlakuan terbaik berdasarkan standar

\begin{tabular}{cccc}
\hline Komposisi & Hasil Analisis & BPOM $^{*}$ & SN $^{* *}$ \\
\hline Kadar Protein & $5.63 \%$ & Min $12 \%$ & Min 5\% \\
Total Lemak & $27.03 \%$ & Max $18 \mathrm{~g} /$ takaran saji & - \\
& 9.5 gram per takaran saji & - & - \\
Karbohidrat & $52.47 \%$ & Min 3\% & - \\
Serat & $31.26 \%$ & Max $300 \mathrm{mg} /$ takaran & saji \\
Natrium & $250 \mathrm{mg} /$ takaran saji & Max 4 g/takaran saji & - \\
& & $60 \mathrm{mg} /$ takaran saji & - \\
Lemak Jenuh & - & & \\
Kolesterol & - & &
\end{tabular}

Berdasarkan nilai analisis di atas, maka dapat dilihat berdasarkan Acuan Label Gizi (ALG) pada BPOM ${ }^{b}$ (2016), tiap takaran saji cookies sebanyak 35 gram mampu memenuhi kebutuhan protein sebanyak $4 \%$, lemak sebesar $15 \%$, karbohidrat $6 \%$, serat sebesar $37 \%$ dan kalori $7 \%$.

\section{Simpulan}

\section{SIMPULAN}

Cookies perlakuan terbaik dari segi kimia diperoleh dari proporsi tepung kulit buah naga: tepung terigu (90:10) memiliki kadar air $8.06 \%$, kadar abu $6.81 \%$, kadar protein $5.63 \%$, kadar lemak $27.03 \%$, kadar karbohidrat $52.47 \%$, dan kadar serat $31.26 \%$. Setiap takaran saji juga telah memenuhi beberapa persyaratan yang disyaratkan sebagai standar mutu cookies kecuali pada standar kadar air. Dibutuhkan reformulasi komposisi cookies agar kadar air cookies dapat sesuai dengan standar mutu SNI cookies dan diperlukan analisis sensoris untuk mengetahui tingkat penerimaan cookies. Selain itu diperlukan analisis lain seperti kadar lemak jenuh dan kolesterol agar dapat diketahui kesesuaian cookies dengan standar yang berlaku.

\section{DAFTAR PUSTAKA}

[BPOM] Badan Pengawas Obat dan Makanan Republik Indonesia. 2015. Pengawasan Takaran Saji Pangan Olahan. BPOM. Jakarta.

[BPOM$\left.{ }^{a}\right]$ Badan Pengawas Obat dan Makanan Republik Indonesia. 2016. Acuan Label Gizi. BPOM. Jakarta.

[BPOM $\left.{ }^{b}\right]$ Badan Pengawas Obat dan Makanan Republik Indonesia. 2016. Pengawasan Klaim pada Label dan Iklan Pangan Olahan. BPOM. Jakarta.

[BSN] Badan Standardisasi Nasional. 2011. Biskuit (SNI 2973:2011). BSN. Jakarta. 
Akubor, P. (2003). Functional Properties and Performance of Cowpea/Plantain/Wheat Flour Blends in Biscuits. Journal Plant Food Human Nutrition, 58.

AOAC. 1995. Official Methods of Analysis. Washington: Association of Official Analytical Chemists.

Arshad, M. U., Anjum, F. M., and Zahoor, T. 2007. Nutritional Assessment of Cookies Supplemented with Defatted Wheat Germ. Food Chemistry 102, 123-128 1-8.

Astawan, M. 2008. Membuat Mi dan Bihun. Penebar Swadaya: Jakarta.

Butcher, J. L., and Beckstrand, R. L. 2010. Fiber's Impact on High-Sensitivity C-Reactive Protein Levels in Cardiovascular Disease. J. Am. Acad. Nurse Pract. 22:11, 566-572. doi:10.1111/j.1745-7599.2010.00555.x.

Fatkurahman, R., W. Atmaka dan Basito. 2012. Karakteristik Sensoris dan Sifat Fisikokimia Cookies dengan Substitusi Bekatul Beras Hitam (Oryza sativa L.) dan Tepung Jagung (Zea mays L.) Jurnal Teknosains Pangan 1:1, 49-57.

Fauziah, A.I., dan Yunianta. 2019. Pengaruh Perbedaan Formulasi Terhadap Sifat Fisik, Kimia dan Organoleptik pada Muffin Non Terigu. Jurnal Pangan dan Agroindustri 7:2, 1 12.

Hadi, N. A., Mohamad, M., Rohin, M.A.K, and Yusof, R.M. 2016. Effects of Red Pitaya Fruit (Hylocereus polyrhizus) Consumption on Blood Glucose Level and Lipid Profile in Type 2 Diabetic Subjects Borneo Science, 31.

Hernawati, N.A., Setiawan, R. Shintawati, and D. Priyandoko. 2018. The Role of Red Dragon Fruit Peel (Hylocereus polyrhizus) to Improvement Blood Lipid Levels of Hyperlipidaemia Male Mice. Journal of Physics: Conf. Series, 1013: 012167. Doi: 10.1088/17426596/1013/1/012167.

Ho, L., and Nadratul, W. 2016. Nutritional Composition, Physical Properties, and Sensory Evaluation of Cookies Prepared from Wheat flour and Pitaya (Hylocereus undatus) Peel flour Blends. Cogent Food \& Agriculture 2, 1136369.

Hoa, T. T., Clark, C. J., Waddell, B. C., and Woolf, A. B. 2006. Postharvest Quality of Dragon Fruit (Hylocereus undatus) Following Disinfesting Hot Air Treatments. Postharvest Biology and technology 41: 62-9.

Hood, L.M. 1980. Carbohydrates and Health. AVI Publishing Company Inc. Westport. Connecticut.

Lairon, D., Arnault, N., Bertrais, S., Planells, R., Clero, E., Hercberg, S., et al. 2005. Dietary Fiber Intake and Risk Factors for Cardiovascular Disease in French Adults. Am. J. Clin. Nutr. 82:6, 1185-1194.

Montonen, J., Knekt, P., Jarvinen, R., Aromaa, A., and Reunanen, A. 2003. Whole-Grain and Fiber Intake and the Incidence of Type 2 Diabetes. Am. J. Clin. Nutr. 77:3, 622-629.

Nerd, A., Sitrita, Y., Kaushika, R. A., and Mizrahi, Y. 2002. High Summer Temperatures Inhibit Flowering in Vine Pitaya Crops (Hylocereus Spp). Scientia Horticulturae, 96:343-50.

Praptiningrum, W. 2015. Eksperimen Pembuatan Butter Cookies Tepung Kacang Merah Substitusi Tepung Terigu. Skripsi. Universitas Negeri Semarang: Semarang.

Septiani, D. 2016. Mempelajari Pembuatan Cookies Kaya Serat Dengan Bahan Dasar Tepung Asia Ubi Jalar. Skripsi. Institut Pertanian Bogor : Bogor.

Simangunsong, D.R., Osfar,S., dan Irfan, H.D. 2014. Kajian Kandungan Zat Makanan dan Pigmen Antosianin Tiga Jenis Kulit Buah Naga (Hylocereus sp) Sebagai Bahan Pakan Ternak. Universitas Brawijaya: Malang.

Wani, S. H., Gull, A., Allaie, F., and Safapuri, T. A. 2015. Effects of Incorporation of Whey Protein Concentrate on Physicochemical, Texture, and Microbial Evaluation of Developed Cookies. Cogent Food \& Agriculture 1, 1092406.

Welli, Y. 2012. Pemanfaatan Umbi Talas Sebagai Bahan Subsitusi Tepung Terigu dalam Pembuatan Cookies yang Disuplementasi dengan Kacang Hijau. Jurnal Matematika, 13 (2): 94-106.

Wulandari, F.K., B.E., Setiani, dan S. Susanti. 2016. Analisis Kandungan Gizi, Nilai Energi, dan Uji Organoleptik Cookies Tepung Beras dengan Subtitusi Tepung Sukun. Jurnal Aplikasi Teknologi Pangan 5:4, 107-112. 